\title{
British Bryological Society expedition to Mulanje Mountain, Malawi. 15. Lejeuneaceae, and the occurrence and frequency of foliicolous taxa
}

\author{
M. J. Wigginton \\ 36, Big Green, Warmington, Peterborough, PE8 6TU, United Kingdom
}

\begin{abstract}
Details of habitat and location are given for 64 taxa of Lejeuneaceae collected during the BBS expedition to Mulanje Mountain, Malawi in 1991, of which 47 are new to Malawi. The occurrence and frequency of foliicolous taxa are documented.
\end{abstract}

\section{INTRODUCTION}

The background to the expedition, 16-30 June 1991, and details of the localities visited were described in the first paper of this series (Longton, 1993). Prior to this expedition, rather few collections of Lejeuneaceae had been published for Malawi, with only 26 species recorded (O'Shea, 1993). Because of this, a special effort was made to collect Lejeuneaceae during the BBS expedition. The foliicolous collections have all been studied in detail, but only about half of the collections of non-foliicolous Lejeuneaceae have so far been determined to species. As the remaining collections are worked through, it is likely that other species (especially of Lejeunea), will be identified, and further collections discovered of species listed in this paper. Our collections of Colura were published in Porley (1997). In the following list, for species with few records, the site name, $1 \mathrm{~km}$ UTM grid reference, habitat, altitude and specimen number are given, and for those with more records, the collection data are summarised. The conversion of $1 \mathrm{~km}$ UTM grids to degrees and minutes of latitude and longitude is given in Table 2 in order to facilitate any future mapping. The UTM grid references have been derived from the 1:30000 map of Mulanje Mt., published by the British Directorate of Overseas Surveys (1977).

All the collections have been determined by the author unless otherwise indicated. The number on the collections packets are prefixed by the letter $\mathrm{M}$, the letter being omitted in this paper. Collections will be housed at the herbarium of the Royal Botanic Garden, Edinburgh (E), with sub-collections at the National Herbarium, Zomba, Malawi (MAL) and the herbarium of the Botanic Garden, Missouri (MO).

$$
\begin{aligned}
& \text { * new to Malawi } \\
& \text { ** new to mainland Africa. }
\end{aligned}
$$




\section{LIST OF TAXA}

The taxa are listed in alphabetic order. For some of the most frequently recorded species, only selected collections are cited. For species previously recorded in Malawi, the place, collector's name and collection date are given.

Acrolejeunea emergens var. emergens (Mitt.) Steph. Near Likhubula River, 6936, on dry bark of Julbernardia tree, $960 \mathrm{~m}$, Wigginton 1762a. Previous record from Malawi: Mulanje Mt. (A.C. Crundwell, 1969).

Aphanolejeunea capensis (S.W.Arnell) S.W.Arnell Chisongoli, 9127, on tree trunk in open forest, $1630 \mathrm{~m}$, Porley 39c. Nessa path, Lichenya, 7330, 7429, 7431, 7529, epiphyll on forest shrubs, 1700-1820 m, Porley 280b, 287b, 31 la; Wigginton 1719h. Between Nandiwo and Nandalanda, 8241, creeping over Radula boryana and Hymenophyllum sp. on stem of treefern in forest patch, $2220 \mathrm{~m}$, Wigginton $1390 \mathrm{~b}$. Thuchila to Chambe path, 7238 , on granitic boulder, $2020 \mathrm{~m}$, O'Shea 7416b. Sombani Basin, near Forestry Dept., 9041, on mosses on tree bark in open woodland, $2080 \mathrm{~m}$, O'Shea $7247 \mathrm{~b}$. Previous record from Malawi: Mulanje Mt. (L. Ryvarden, 1973)

*Aphanolejeunea microscopica var. microscopica (Taylor) A.Evans Lichenya Plateau, 7529, epiphyll on forest shrub, 17501800 m, Porley 280d, 287y, det. T. Pócs.

*Aphanolejeunea microscopica var. exigua (A.Evans) Pócs \& Lücking Slopes of Sapitwa, 7635, creeping over Tetralophozia cavallii and other bryophytes, $2770 \mathrm{~m}$, Porley $250 \mathrm{~b}$.

*Aphanolejeunea microscopica var. africana (Pócs) Pócs \& Lücking Ruo, Nessa path, Lichenya, 7232, 7431, 7429, 7529, 8239, epiphyll on forest shrubs and ferns, 1680-1900 m, Porley 111d, 271j; Hodgetts 2522d; Wigginton 1719j; O'Shea $7500 j$.

*Aphanolejeunea truncatifolia Horik. Little Lujeri Forest, 8032, epiphyll on Dracaena steudneri and a broad-leaved forest shrub, 1200 m, Russell 6002a; O'Shea 7047a, det. T. Pócs.
Originally thought to be new for Africa, but a 1947 collection from Bioko was reported in Infante et al. (1997).

*Archilejeunea abbreviata (Mitt.) Vanden Berghen The Crater, by Muloza river, 7227, on trunk of large forest tree, $920 \mathrm{~m}$, Longton 8657 , 8660e.

Caudalejeunea sp. Shoots of Caudalejeunea occurred occasionally in foliicolous collections, but almost all were sterile and indeterminate.

*Caudalejeunea hanningtonii (Mitt.) Schiffn. The Crater, 7227, epiphyll on forest shrub, 940 m, O'Shea $7586 a$.

*Caudalejeunea lewallei Vanden Berghen Nessa path, Lichenya, 7529, epiphyll on forest shrub, $1800 \mathrm{~m}$, Porley $280 \mathrm{~g}$. Little Lujeri Gorge, 8032, epiphyll on Dracaena in forest, $1200 \mathrm{~m}$, Russell 6002e.

*Ceratolejeunea jungneri Steph. Ruo Gorge, 8433, epiphyll on Hymenophyllum on buttress of forest tree, $1075 \mathrm{~m}$, Porley $94 \mathrm{~b}$. Chisongoli, 9126 , on trunk of small tree with other Lejeuneaceae, Radula sp., Plagiochila spp., 1230 $\mathrm{m}$, Wigginton 1022c. Lower Ruo Forest, 8434, on tree buttress creeping amongst Anastrophyllum piligerum, Bazzania decrescens, Lejeunea flava, Mastigophora diclados, Plagiochila sp., $1020 \mathrm{~m}$, Wigginton 1184e, $1187 c$, det. E.W.Jones. The Crater, 7227 , on boulder in stream, $900 \mathrm{~m}$, O'Shea $7546 a$. Vanden Berghen (1951) separated $C$. jungneri from $C$. calabariensis by the length of the perianth horns. However, there is a complete gradation in length, and T. Pócs (pers. comm.) considers they cannot be maintained as a separate species, $C$.jungneri taking precedence. Malawi collections also show a range of perianth horn length, and have all been assigned to $C$. jungneri.

*Cheilolejeunea cordistipula (Steph.) Grolle ex E.W.Jones S. of Minunu Hut, above Ruo Gorge, 8337, stems and branches of well-lit shrub in grass/shrub community on plateau, $1980 \mathrm{~m}$, Wigginton $1275 b$. Ruo Gorge, 8337, stem of small shrub at forest edge, with Leucolejeunea 
rotundistipula, L. xanthocarpa and Drepanolejeunea physaefolia, $1880 \mathrm{~m}$, Wigginton 1248 e. Malosa Pools, 8740, epiphytic on ericaceous shrub, 2080 m, Kungu 3086a. Sapitwa, 7735, on tree bark, with Cheilolejeunea pluriplicata and Diplasiolejeunea cornuta, 2900 m, Magombo 4306b, $4308 a$.

*Cheilolejeunea krakakammae (Lindenb.) R.M.Schust. Lichenya Plateau, 7330, on twigs fallen from forest canopy, creeping over Macrocoma tenuis, with Leucolejeunea xanthocarpa, Lejeunea sp., 1820 m, Porley 313c. Thuchila Plateau, 7941, on trunk of small tree in open site, $1970 \mathrm{~m}$, Wigginton 1400b. Chambe Basin, 7239, on trunk of Trichlia emetica with Frullania obscurifolia, Microlejeunea africana, Trichosteleum sp., in spruce woodland, $1900 \mathrm{~m}$, Wigginton 1546a.

*Cheilolejeunea pluriplicata (Pearson) R.M.Schust. Sapitwa Mt., 7735, on tree bark, with C. cordistipula, 2900 m, Magombo 4306a, 4308c. S. of Minunu Hut, 8433, on tree branch, with C. usambarana, $990 \mathrm{~m}$, O'Shea $7069 \mathrm{~b}$.

*Cheilolejeunea pocsii E.W.Jones Chisongoli, 9127, epiphytic on stems of Papillaria sp., on shaded trunk of sapling in forest, $1660 \mathrm{~m}$, Wigginton $1073 \mathrm{~b}$. This collection differs from typical $C$. pocsii in its rather smaller underleaves, often only 1.3-2.0 times the width of the stem.

*Cheilolejeunea surrepens (Mitt.) E.W.Jones Chisongoli, 9127, on trunks of small forest trees, 1635 m, Wigginton 1047d, 1068c.

*Cheilolejeunea usambarana (Steph.) Grolle The Crater, 7227, on rotten tree trunk lying across stream, 950 m, Hodgetts 2683a. S. of Minunu Hut, 8433, on tree branch, with $C$. pluriplicata, 990 m, O'Shea 7069a. Madzeka path, 8532, on granitic boulder, with Schiffneriolejeunea pappeana and Lejeunea sp., $930 \mathrm{~m}$, Longton $8020 a$.

*Cololejeunea appressa (A.Evans) Benedix Epiphyll in several localities on the southern slopes of Mt. Mulanje, but in tiny quantity and on very few leaves: The Crater, Upper and Lower
Ruo Forest, Chisongoli, 7227, 8335, 8434, 9127, 920-1625 m, Porley 38j; Hodgetts 2666b; Kungu 3073e; Magombo 4106c. The Crater, 7227, on bark of large tree in Newtonia forest by river, 920 m, Longton $8660 f$.

*Cololejeunea cardiocarpa (Mont.) A.Evans Chisongoli, Lichenya Plateau, The Crater, 7227, $7330,7332,7429,7431,9127$, epiphyll on forest shrubs, usually in very small quantity, 920-1820 m, Porley 311b; Wigginton 1720e; Hodgetts 2231b, 2666d; O'Shea 7581f.

*Cololejeunea distalopapillata (E.W.Jones) R.M.Schust.Chisongoli, Thuchila Plateau, Dzole, Minunu, Chambe Basin, Lichenya, 7227, 7240, 7429, 7431, 7840, 7939, 8337, 9127, epiphyll on forest shrubs and ferns, 920-2020 m, Porley 52b; Wigginton 1489q, 1492b, 1493a; Hodgetts 2389e, 2403c, 2666f; Kungu 3073a; Longton 8401a. This was one of the most frequent foliicolous species in our collections.

*Cololejeunea duvignaudii E.W.Jones Ruo Forest, Nessa path (Lichenya), Little Lujeri, 7529, 8032, epiphyll on forest shrubs, 1020-1820 m, Porley 287c; Hodgetts 2542g, 2554g; Russell 6002d; O'Shea 7047d.

*Cololejeunea elegans (Steph.) E.W.Jones Ruo Forest, Nessa path (Lichenya), 7429, 7529, 8433 , epiphyll on shaded forest shrubs and ferns, but particularly on Hymenophyllum spp. hanging from tree trunks and buttresses, 1020-1800 m, Porley 94d; Wigginton 1185a; Hodgetts 2574e, 2575 s.

Cololejeunea latilobula (Herzog) Tixier Near Likhubula River, 6936, closely appressed to rough-surfaced granitic boulder by river, in humid but moderately exposed location, $980 \mathrm{~m}$, Wigginton 1755a. Previous records in Malawi: Mirale Forest Reserve (E.W. Jones, 1955); Limbe (A.C. Crundwell, 1969). Tixier (1985) made $C$. himalayensis a synonym of $C$. latilobula (Herzog) Tixier, but E.W.Jones (in MS) considered that this synonymy requires confirmation.

*Cololejeunea lichenyae ined. This foliicolous 
taxon, related to $C$. harrisii Pócs, was found on ferns and broad-leaved shrubs within forest and in humid streamside sites, but only in the vicinity of the Nessa path, south of Lichenya: 7429, 7529, 1800-1820 m, Porley 271h, 279d; Hodgetts 2554hh, 2558a, 2569f. Some collections were fertile, with mature perianths. The species will be described in a forthcoming paper (Wigginton, Hodgetts \& Porley, in prep.).

Cololejeunea malanjae Steph. The most frequent and abundant epiphyll on Mulanje Mt.: Chisongoli, Nessa path (Lichenya), Lichenya Plateau, Thuchila, Ruo Gorge, 7232, 7330, 7429, $7431,7529,7840,8237,9127$, epiphyll on broadleaved understorey shrubs in forest, 1250-1900 $\mathrm{m}$, Porley 38d, 54a, 280e, 311c; Wigginton 1492c; Hodgetts 2231e, 2522h, 2554h, 2574c; Magombo 4383a; O'Shea 7500c. Previous records from Malawi: Mulanje Mt. (W. Scott Elliott, 1894); 'Nyasa See, Ulugura Berge' (Goetze, 1898).

Cololejeunea minutissima (Sm.) Schiffn. Near Madzeka path, Ruo Valley, 8632, on granitic boulder in fire-break, $1080 \mathrm{~m}$, O'Shea $7031 \mathrm{c}$. Previous record from Malawi: Limbe (A.C. Crundwell, 1969).

Cololejeunea minutissima subsp. myriocarpa (Nees \& Mont.) R.M.Schust. Dzole, Chisongoli, 9127, on shaded rock in cleared area of forest, $1540 \mathrm{~m}$, Wigginton 1107a, conf. T. Pócs. Lichenya: 7332, 7939, rare and very sparse epiphyll on forest shrubs, 1780-2020 m, Hodgetts $2378 c$ 7528f. Madzeka path, 8532, on granitic boulder, creeping over Cheilolejeunea usambarana and Schiffneriolejeunea pappeana, 930 m, Longton 8020d. Previous record from Malawi: Zomba Plateau (T. Pócs, 1991).

*Cololejeunea mocambiquensis S.W.Arnell Thuchila Plateau, 7841, epiphytic on Porotrichum usagarum on shaded rock in forest, 1760 m, Wigginton 1430a, det. T. Pócs. Shoots of C. mocambiquensis were found on only c. 20 fronds of Porotrichum usagarum in this bulky collection. C. mocambiquensis was not observed in any other of our numerous collections of Porotrichum or other robust mosses.
*Cololejeunea obtusifolia (E.W.Jones) Tixier A local and sparse epiphyll on forest shrubs, and apparently confined to lower altitudes on Mulanje Mt.: Ruo Forest, The Crater, 7227, 8335, 8434, 920-1250 m, Hodgetts 2666g; Kungu 3073c; Magombo 4106a.

*Cololejeunea occidentalis (E.W.Jones) Vanden Berghen Chisongoli, 9127, epiphyll on shrub, 1625-1710 m, Porley 38a, 47a. Lichenya river, 7431, epiphyll on shrub, 1700 $\mathrm{m}$, Wigginton 1719b, comm. E.W.Jones. Nessa path, Lichenya Plateau, 7429, epiphyll on forest shrub, $1800 \mathrm{~m}$, Hodgetts 2574u. The Crater, 7227, epiphyll on shrub by stream, $950 \mathrm{~m}$, O'Shea 7581d. Because the group of similar species including C. africana and C.occidentalis is poorly understood, naming our Malawi collections has been a little uncertain. However, I have mainly followed Vanden Berghen (1978), and assigned all of them to $C$. occidentalis on the basis of 1) the size of the mature lobes (550$850 \times 900-1100 \mu \mathrm{m}), 2)$ the size of the apical hyaline cells (c. $15 \times$ 40-52 $\mu \mathrm{m}$ to $19 \times 55-75 \mu \mathrm{m}$ ), and 3 ) the hyaline cells gradually reducing in size along the postical margin of the lobe and ceasing c. 10-12 cells from the keel. However, all our collections differ in the marginal hyaline cells being mostly deeply crenulate rather than fimbriate, and the apical tooth being blunt or short.

*Cololejeunea platyneura (Spruce) A.Evans A very frequent epiphyll on ferns and shrubs in forest and other shaded places; very rare on tree trunks: Chisongoli, Nessa path, Lichenya Plateau, Lower Ruo, 7429, 7431, 7529, 8434, 9126, 10051820 m, Porley 280k, 281c, 287c, 298d; Hodgetts 2522i, 2542b, 2554i, 2574v; Magombo 4387e.

*Cololejeunea runssorensis (Steph.) Pócs Nessa path, Lichenya Plateau; 7232, 7529, epiphyll on forest shrub and fern; 1750-1800 m; Porley 271f; O'Shea 7500d.

*Cololejeunea tanneri Pócs Little Lujeri Gorge, 8032, rare epiphyll on a forest shrub, $1200 \mathrm{~m}$, Russell 6002f, conf. T. Pócs. This is the second record of a species which is otherwise known only from the type collection from the Usambara Mts., Tanzania (Pócs, 1985). 
*Cololejeunea tanzaniae Pócs Thuchila Plateau, 7840, epiphyll on shrub and small tree in forest understorey, 1730-1760 m, Wigginton 1489k, 1492a, conf. T. Pócs.

*Cololejeunea tonkinensis Steph. Upper and Lower Ruo, The Crater, Little Lujeri, 7227, 8032, 8337,8434 , epiphyll on forest shrubs, usually in small quantity, at the lower altitudes on the mountain, 920-1250 m, Hodgetts 2666h; Kungu 3073d; Magombo 4106d; Russell 6002c; O'Shea 7047b, 7581e.

*Cololejeunea zenkeri (Steph.) E.W.Jones A very locally frequent epiphyll on forest shrubs and ferns, found only on the Lichenya Plateau and in forest bordering Nessa path (Lichenya), 7429, 7529, $1800 \mathrm{~m}$, Hodgetts 2542k, 2569c, $2574 a, 2575 p$.

*Diplasiolejeunea cornuta Steph. A fairly widespread epiphyll on forest shrubs and ferns, but always in very small quantity. Chisongoli, Nessa path, Lichenya, Ruo Gorge, 7330, 7332, 7333, 7431, 7840, 8237, 9127, 1680-2900 m, Porley 52d; Wigginton 1719d; Hodgetts 2242e, $2589 t, 2595 e$. Near Minunu Hut, 8237, on stem of Kotschya scaberrima (Leguminosae) in grassheath, 2000 m, Porley 125a. Sapitwa Mt., 7735, on tree bark, with Cheilolejeunea spp., $2900 \mathrm{~m}$, Magombo $4308 d$.

*Diplasiolejeunea kraussiana (Lindenb.) Steph. A locally frequent epiphyll on leaves of small trees and forest shrubs, but found only on the Thuchila and Lichenya Plateaux, within a small altitude range: 7232, 7840, 1700-1750 m, Porley 217c; Wigginton 1489r; Hodgetts 2378d; O'Shea $7500 \mathrm{~g}$.

**Diplasiolejeunea subcornuta Tixier Minunu, 8337, epiphyte on stems of leguminous shrub in shrub-grass community, $2000 \mathrm{~m}$, Wigginton $1262 a$, det. T. Pócs.

*Diplasiolejeunea symoensii Vanden Berghen Epiphyll on forest shrubs and ferns, Chisongoli, Lichenya, Nessa path, 7330, 7332, 7429, 7529, 9127, 1625-1820 m, Porley 38g, 52d, 311b; Wigginton 1720c; Hodgetts 2567f, 2569j.
*Diplasiolejeunea villaumei Steph. Nessa path, Lichenya; 7330, 7331, on twigs of a forest shrub, with some plants growing on leaf petioles and the blade (but hardly an epiphyll), 1720 and 1780 $\mathrm{m}$, Wigginton 1662a, Hodgetts 2589s. Lichenya Plateau, near Lichenya River, 7331, on tree branch in riverine forest, growing with Leucolejeunea xanthocarpa, 1720 m, Kungu $3329 a$.

*Drepanolejeunea cultrella agg. The recognition and delimitation of species within the D. cultrella complex is difficult because of 1) the great variability in the morphology of leaves, especially in dentition, even within a single collection, the leaves on strong main axes often being very different from those on branches or weak shoots, 2) the infrequent occurrence of perianths in dioecious species, and 3) the variable number and position of ocelli, which, in addition, are apparently not present in every leaf. Such difficulties have led to a divergence of opinion amongst taxonomists, with some taxa being variously recognised as species, varieties, or merely morphological variants. Taxa in the $D$. cultrella complex occurred mainly in the Mt. Mulanje foliicolous collections, and were well represented there, with only Cololejeunea malanjae and $C$. platyneura more frequent in terms of their presence on examined leaves. However, there was considerable variation in leaf form and dentition: in some collections only slight dentition, in others a prominent postical tooth, and in others prominent dentition on the antical margin. Depending on what literature is consulted, such forms could be assigned to $D$. cultrella (Mitt.) Steph., D. ruandensis Vanden Berghen, perhaps even to D. cambouena Steph. (according to expert opinion). The latter is, however, a poorly-described and little-known species. In one collection ( $O$ 'Shea $7455 \mathrm{c}$ ), the leaves are remarkable in possessing a long narrow 'tooth' of uniseriate cells on the postical margin near the insertion of the lobule - a similar form to that of the southeast Asian D. pentadactyla (e.g. illustration in Herzog (1934), as $D$. micholitzii var. dactylophoroides). Because of the taxonomic uncertainties, all collections have been placed in $D$. cultrella agg. for the time being pending further studies of this complex. A 
frequent epiphyll particularly on sclerophyllous leaves, rarely on twigs; Chisongoli, Lichenya, Nessa path, Thuchila Plateau, 7232, 7330, 7429, 7431, 7529, 7840, 9127, 1625-1800 m, Porley 311e; Wigginton 1489n, 1493g; Hodgetts 2389a, 2595g; O'Shea 7455c, 7500b, 7500n. Several collections are abundantly fertile, with mature perianths.

Drepanolejeunea physaefolia (Gottsche) Steph. A very frequent epiphyte on tree trunks, branches and twigs, occurring either as scattered stems intricately intertwined in tufts of more robust hepatics and mosses, or in mixed bryophyte mats, or in small 'pure' patches. Rare on rocks, and very rare as an epiphyll. Chisongoli, Crater, Nessa path, Lichenya, Ruo, 7227, 7529, 8337, 9126, 885-1880 m, Porley 287j, 327b; Wigginton 1017a, 1248a; Magombo 4052b; O'Shea 7164a, 7500h. Previous record from Malawi: Mulanje Mt. (T. Pócs, 1991). Perianths are rare in this dioecious species, and mature perianths have not been detected in our Malawi collections, although in some collections fully grown bracts and bracteoles are common, but concealing only embryonic, hardly-formed perianths. The relationship of this taxon with the Asian $D$. vesiculosa (Mitt.) Steph. requires further study. Tixier (1995) made D. physaefolia its synonym, but Grolle (1995) considered that their conspecificity is still an open question.

*Drepanolejeunea pocsii Grolle A rather local epiphyll on broad-leaved shrubs and Dracaena in humid forest, sometimes in abundance on individual leaves. Nessa path, Lichenya, and Little Lujeri Forest, 7429, 7529, 8032, 1200-1800 m, Porley 280f; Hodgetts 2522s, M2569r; Russell 6002b; O'Shea 7047i.

* Lejeunea caespitosa Lindenb., in Gottsche et al. Nessa path, Lichenya, Thuchila, 7232, 7529, 7840, 1730-1760 m, Porley 287k; Wigginton 1489d, 1493e; Hodgetts 2574x; Magombo 4387c; $O$ 'Shea $7500 p$. Only fertile material has been determined, but the occurrence of similar sterile material suggests this is probably a frequent epiphyll on forest shrubs.

*Lejeunea confusa E.W.Jones Chisongoli,
9127, epiphyllous on forest shrubs, $1680 \mathrm{~m}$, Hodgetts 2231i. Nessa path, Lichenya Plateau, 7529, epiphyll on forest shrub, $1820 \mathrm{~m}$, Hodgetts $2554 w$. Chisongoli, 9127, on twigs of forest shrub, $1680 \mathrm{~m}$, Hodgetts $2231 \mathrm{~h}$.

Lejeunea eckloniana Lindenb., in Gottsche et al. Epiphyll on forest shrubs and saplings: Nessa path, Lichenya, between Dzole and Khutu, 7232, 7529, 7840, 7939, 1730-2020 m, Porley 281g; Wigginton 1489c; Hodgetts 2403f, 2554x; O'Shea $7500 k$.

Lejeunea flava agg. Taxa of this group occurred frequently in our foliicolous and other collections, though the material was often sterile and sometimes indeterminate. Most collections appear to be L. flava subsp. tabularis, but few collections have yet been sufficiently studied.

*Lejeunea hepaticola (Steph.) Steph. Near Minunu, 8237, epiphytic on base of leguminous shrub, with Diplasiolejeunea cornuta, Lejeunea flava agg., Leucolejeunea xanthocarpa, Microlejeunea africana, Schiffneriolejeunea pappeana in grass-shrub community on plateau, $2000 \mathrm{~m}$, Wigginton 1262b. Near Minunu firebreak, 8337, stem and branches of shrub in grass/shrub community, $1980 \mathrm{~m}$, Wigginton 1275d. Lichenya River, 7431, epiphyll on fern in forest near river, $1700 \mathrm{~m}$, Wigginton $1719 f$. Nessa path, Lichenya, 7330, on twigs and leaves overhanging forest stream, $1780 \mathrm{~m}$, Hodgetts $2595 j$.

Lejeunea isophylla E.W.Jones Chisongoli, 9227, on base of forest tree, $1680 \mathrm{~m}$, Wigginton 1081c. Near Lichenya Rest House, 7232, amongst other bryophytes on tree branch, 1720 m, O'Shea 7490d. Previous record: Mulanje Mt. (F.G.H. Lupton, 1947).

*Lejeunea "longilobulata” ined. Upper Ruo Gorge, 8237, epiphyll on tree-fern, $1900 \mathrm{~m}$, Porley $111 \mathrm{~b}$. Thuchila, 7840, epiphyll on forest shrub and sapling, $1730 \mathrm{~m}$, Wigginton $1489 \mathrm{~g}$, Hodgetts 2389d. This taxon was described and given this "working" name by E.W.Jones in an unpublished draft account of the Lejeunea flava complex. It is similar to L. tabularis, differing 
mainly in the inrolled free margin of the lobule being bordered by $5-10$ cells (normally 4 cells in L. tabularis). Jones described this taxon from Kenyan and Tanzanian specimens, where it is known as an epiphyte and epiphyll on a wide range of trees and shrubs, including bamboo. The recorded altitude range is $1700-3070 \mathrm{~m}$.

Lejeunea tabularis (Spreng.) Gottsche, in Gottsche et al. Thuchila Plateau, 7840, epiphyll on forest shrub, $1750 \mathrm{~m}$, Wigginton 1489f; Hodgetts 2378j. Chambe to Lichenya path, 7233, epiphytic on Hymenophyllum on Widdringtonia cupressoides, $2045 \mathrm{~m}$, O'Shea $7426 a$.

Tubata form: Near Lichenya River, 7232, on leaves of shrub on stream bank, $1750 \mathrm{~m}$, O'Shea 7500s; epiphytic on bamboo, $1720 \mathrm{~m}$, Longton 8516b. Previous record from Malawi: Zomba Plateau (A.C. Crundwell, 1969).

Lejeunea tuberculosa Steph. Chisongoli, 9227, trunk of small forest tree, $1680 \mathrm{~m}$, Wigginton 1091c. Madzeka path, 8532, bark of Mangifera tree, $965 \mathrm{~m}$, O'Shea 7022a, 7023d. The Crater, 7227, trunk of large tree in Newtonia forest, 920 $\mathrm{m}$, Longton 8660a. Only collections with perianths have been determined. Previous record from Malawi: Mirale Forest Reserve (E.W. Jones, 1955). African collections were formerly placed under its synonym, L. camerunensis (Steph.) E.W.Jones.

*Lejeunea villaumei (Steph.) Grolle Nessa path, Lichenya, 7529, epiphyll on forest shrub, $1820 \mathrm{~m}$, Hodgetts $2554 t$.

*Leucolejeunea rotundistipula (Lindenb. ex Lehm.) A.Evans Chisongoli, 9127, on vertical side of granitic rock in cleared area of forest, 1560 $\mathrm{m}$, Wigginton 1103b. Chisongoli, 9126, on rock in open area along path, $1220 \mathrm{~m}$, Magombo $4067 a$. Minunu path, Ruo valley, 8435 , on rotting $\log , 1110$ m, O'Shea 7079e. Ruo Forest, 8337, on stem of small shrub, with L. xanthocarpa, Cheilolejeunea cordistipula, Drepanolejeunea physaefolia, $1880 \mathrm{~m}$, Wigginton 1248a, conf. R. Grolle. L. rotundistipula can be very similar to Cheilolejeunea cordistipula in colour, size and general morphology, and it is possible that one or the other might have been overlooked in other mixed collections, especially where present in small amounts. The apical tooth in some plants of $L$. rotundistipula varies in length and sharpness, but the lack of a sinus at the junction of the lobule and lobe, and the small underleaves clearly point to this species.

*Leucolejeunea xanthocarpa (Lehm. \& Lindenb.) A.Evans Frequent on trunks, branches and twigs (including canopy twigs) on a wide range of trees and shrubs, including bamboo, and rare as an epiphyll. Usually in small quantities and often in mixed lejeuneaceous communities, or creeping over mat-forming mosses, often abundantly fertile. Associates included Cheilolejeunea cordistipula, Diplasiolejeunea villaumei, Drepanolejeunea physaefolia, Leucolejeunea rotundistipula, Schiffneriolejeunea pappeana. Lichenya, Malosa Pools, Minunu, Ruo, 7330, 7331, 7333, 7532, 8237, 8337, 8740, 1700-2080 m, Porley 313b; Wigginton 1248b, 1275a, 1727a; Kungu 3086b, $3329 b$; O'Shea $7513 a$.

*Lopholejeunea laciniata E.W.Jones Chisongoli, 9126, base of small tree in open forest, $1230 \mathrm{~m}$, Wigginton 1027b. Chisongoli, 9227 , branch of fallen tree in forest, $1680 \mathrm{~m}$, Wigginton 1099e.

Lopholejeunea nigricans (Lindenb.) Schiffn. Only plants with mature perianths are cited. Thuchila valley, 7438 , on tree trunk in broadleaved evergreen woodland, $1920 \mathrm{~m}$, Kungu 3244a (plants in this collection have strongly dentate bracteoles and female bracts, and conform to the former var. fragilis of L. abortica). Muluzi River, Chisongoli, 9127, on rocks by river, $1220 \mathrm{~m}$, Porley 9a. Chisongoli, 9127, closely appressed to granitic rock, $1635 \mathrm{~m}$, Wigginton 1067a. Madzeka path, Ruo valley, 8532 , on granitic rock by stream in riverine forest, $930 \mathrm{~m}$, Longton 8009a. Previous record from Malawi: Zomba Plateau (D.G. Long, 1985).

Marchesinia madagassa Steph. Between Thuchila and Chambe, 7438, tree trunk in forest, $1900 \mathrm{~m}$, Wigginton 1590a. Previous records from Malawi: Ndirande (E.W. Jones, 1955); Zomba Plateau (D.G. Long, 1985). 
Microlejeunea africana Steph. A frequent epiphyll and bark epiphyte, but often in small quantity. e.g. Lichenya River, 7331, tree trunk in humid forest, $1720 \mathrm{~m}$, Wigginton 1655a. By Muloza River, The Crater, 7227, on rotting branch in Newtonia forest, $920 \mathrm{~m}$, Longton 8651a. Previous records from Malawi: Limbe (A.C. Crundwell, 1969); Ndirande (A.C. Crundwell, 1969); Mpingwe Hill (E.W. Jones, 1955); Zomba Plateau (A.C. Crundwell, 1969); Mulanje Mt. (A.C. Crundwell, 1969, L. Ryvarden, 1973).

*Microlejeunea kamerunensis Steph. A scarce epiphyll, and bark epiphyte. e.g. Lichenya Plateau, Nessa path, 7529, epiphyllous on forest shrub, $1750 \mathrm{~m}$, Porley 287s. Madzeka path, 8532 , on shaded granitic rock, 1050 m, Kungu $3013 b$.

*Prionolejeunea grata (Gottsche) Schiffn. Lujeri Gorge, 8031, creeping over other bryophytes on rotting $\log$ in forest, $1180 \mathrm{~m}$, o'Shea $7063 d$.

Ptychanthus striatus (Lehm. \& Lindenb.) Nees A common epiphyte of shaded sites, on trunks, branches and small twigs of trees, and on shrubs and lianes; often abundant, and usually abundantly fertile. Rare on shaded rock. Widespread on Mt. Mulanje: Chambe, Chisongoli, Lujeri, Minunu, Sombani, Thuchila, 7239, 7240, 7438, 7840, 8032, 8335, 9041, 9127 , 1200-2080 m, Wigginton 1547a, 1558a, 1582a; Magombo 4241a; Russell 6018b; O'Shea 7056a, 7060a, 7085b, 7248a, Longton 8396a, 8423a. Previous records from Malawi: Soche (A.C. Crundwell, 1969); Ndirande (E.W. Jones, 1955); Zomba Plateau (A.C. Crundwell, 1969, D.G. Long, 1985); Mulanje Mt. (L. Ryvarden, 1973, Pócs, 1991).

Schiffneriolejeunea pappeana var. pappeana (Nees) Gradst. On twigs and small branches in the forest canopy, and on trees and shrubs at the forest edge; often very widespread and frequent. Chinzama to Sombani path, Chisongoli, Lichenya, Minunu, Ruo, Thuchila, 7239, 7240, 7438, 7939, 8237, 8337, 8441, 1380-2180 m, Porley 48a, 114a, 224a, 316c; Wigginton 1098e, 1544b; Russell 6071a; O'Shea 7092a, 7315a; Longton $8168 a, 8288 a, 8392 a$. 8460a. Previous records from Malawi: Zomba Plateau (A.C. Crundwell, 1969); Mulanje Mt. (A. Gepp, 1894, F.G.H. Lupton, 1947).

*Schiffneriolejeunea polycarpa (Nees) Gradst. Madzeka path, 8532, bark of Mangifera indica, 965 m, O'Shea 7014b. Lujeri Forest, 8032, on twigs, $1200 \mathrm{~m}$, O'Shea $7061 a$.

Taxilejeunea conformis (Nees \& Mont.) Steph. An occasional epiphyll on forest shrubs, and bark epiphyte. Chinzama to Sombani, Chisongoli, Lichenya, Little Lujeri river, 7429, 7529, 7532, 8032, 8441, 9126, 1200-1800 m, Porley 271k, 280m, 298n; Wigginton 1033a; Hodgetts 2522b; O'Shea 7051d, 7323d, 7519g. Previous records from Malawi: Limbe (A.C. Crundwell, 1969); Mirale Forest Reserve (E.W. Jones, 1955); Zomba Mt. (E.W. Jones, 1955).

\section{FOLIICOLOUS COLLECTIONS}

\section{Background}

The study of foliicolous bryophyte communities in sub-Saharan Africa has a long history, the first published being that of Busse (1905), but there was a long interval thereafter until the studies of Thorold (1955), Harrington (1967) and Olarinmoye $(1974,1975)$. Pócs (1977) published a detailed account of the foliicolous communities of East Africa (Kenya and Tanzania), and compared the African foliicolous flora with that of other continents. A few other studies have been published, notably by Pócs for the Comoro Islands (Pócs, 1993) and for the Seychelles and Mauritius (Pócs \& Tóthmérész, 1997). Studies of the occurrence of foliicolous species and endemism in the African liverwort flora were published in Pócs $(1997,1999)$, and there have been many published accounts of individual foliicolous taxa.

In his study of East African communities, Pócs (1977) recorded the numbers of individual plantlets per leaf, and tabulated the total number of plantlets recorded for each taxon (Pócs, 1977, 
Table 3). Plantlets were not counted in the Mulanje collections, so a direct comparison between the two data sets is not straightforward. However, some of the original Tanzanian data which was summarised in Pócs (1977) was presented in Pócs \& Tóthmérész (1997) for individual relevés, and this does suggest that there is generally a positive correlation between the total number of plantlets and the frequency of occurrence of the taxon on leaves. A more ready comparison is possible with the constancy of occurrence of taxa in collections (relevés).

\section{The Mulanje Mt. collections}

Foliicolous liverworts occurred in most of the forest areas visited on Mulanje Mt. in 1991, though they were generally very localised, and sometimes occurred in only small quantities on only a few host plants in a particular locality. Most collections (42) were from montane forest between 1600-1850 m where most of our collecting was concentrated (Chambe, Chisongoli, Lichenya River and Nessa path, Upper Ruo Gorge, Thuchila Plateau), with only 9 collections from submontane forest between 950-1250 m (The Crater, Lujeri, Lower Ruo Gorge), and only 4 small collections from upper montane forest between 1900-2020 m. It seems likely that further surveys of these forests will reveal additional foliicolous species, in particular from submontane forest in the deepest parts of the most humid valleys on the southern and eastern sides of Mulanje Mt. Most collections were from small, sclerophyllous-leaved shrubs, with some from ferns and Hymenophyllum spp. The number of leaves in each collection ranged from 4 to 38 , reflecting the frequency and diversity at the collection site and on the particular host plant. At each location, we mostly collected leaves which appeared to have the greatest diversity or amounts of foliicolous species, but also collected leaves on which foliicolous bryophytes were sparse. Only the presence of foliicolous taxa was recorded on each of the 797 leaves examined, and no attempt was made to document either cover-abundance or the number of plantlets.

Data on the occurrence of the Mulanje Mt. foliicolous taxa are summarised in Table 1, which shows for each taxon the number of leaves on which it occurred, the number of collections in which it was found, and the constancy of its occurrence in collections. By far the most frequently occurring species on leaves was the appropriately named Cololejeunea malanjae, recorded on 323 leaves ( $40.5 \%$ of the total) in 38 collections ( $75 \%$ of the total). The next most common species, $C$. platyneura, occurred at less than half the frequency of $C$. malanjae, being found on 155 leaves ( $21 \%$ of the total) in 19 collections (19\% of the total). The other taxa which were recorded on more than 50 leaves were Drepanolejeunea cultrella agg. (101), Cololejeunea distalopapillata (85), Drepanolejeunea symoensii (84) and Aphanolejeunea capensis (81), Diplasiolejeunea kraussiana (64) and Taxilejeunea conformis (52). The most constant taxa in terms of occurrence in collections (relevés) are shown in columns 2, 5 and 8 of Table 1 .

Since sampling of the submontane forest on Mulanje Mt. was limited, comparisons of the floras of submontane and montane forest must be tentative. A rigorous comparison of foliicolous collections from Mulanje Mt. and other areas must also await further sampling. However, the foliicolous flora on Mulanje Mt. had certain similarities with that described for Tanzania and Kenya (Pócs, 1977). In particular, that 1) several of the most frequent species on Mulanje Mt. were also among the most frequent in the collections from Tanzania and Kenya - e.g. Cololejeunea mulanje (as C. grossidens), Drepanolejeunea cultrella, Microlejeunea africana, 2) some species common to both areas tended to occur at lower elevations on Mulanje Mt. than on mountains in Tanzania and Kenya, 3) Cololejeunea appressa, C. obtusifolia and $C$. tonkinensis occurred preferentially in submontane forest below $1250 \mathrm{~m}$ in both areas, and 4) Aphanolejeunea capensis, A. microscopica var. exigua, Cololejeunea tanzaniae, Colura tenuicornis, Diplasiolejeunea cornuta, Lejeunea caespitosa, L. confusa, L. isophylla and Metzgeria consanguinea were recorded only in higher altitude forest in both areas. 
Differences are also apparent. For example, 1) the sampled areas of Tanzania / Kenya were richer in foliicolous species, with $\mathrm{ca} .90$ liverworts recorded (compared with $c a$. 70 for Mulanje Mt.), including common species which were rare or not recorded on Mulanje Mt. (e.g. Cololejeunea duvignaudii, Drepanolejeunea pocsii, D. trematodes, Leptolejeunea spp., Radula stenocalyx), and 2) taxa recorded frequently in foliicolous collections from Mulanje Mt. but not in those from Tanzania / Kenya included Colura usambarica, Diplasiolejeunea kraussiana, D. symoensii (one plantlet only in the Tanzania / Kenya collections).

\section{Acknowledgements}

I am indebted to Professor Tamas Pócs, Dr Riclef Grolle and the late Dr Eustace Jones for commenting on, confirming or determining specimens from our collections. Thanks also to Gabriella Kis for the loan of collections from Eger (EGR), and to Brian O'Shea for helpful comments.

\section{References}

Busse, W. 1905. Über das Auftreten epiphyllischer Kryptogamen im Regenwaldgebiet von Kamerun. Bericht der Deutschen Botanischen Gesellschaft 23: 164-172.

Grolle, R. 1995. The Hepaticae and Anthocerotae of the East African Islands. An Annotated Catalogue. Bryophytorum Bibliotheca 48: 1178.

Harrington, A.J. 1967. Ecology of epiphyllous liverworts in Sierra Leone. Unpublished report submitted to the Royal Society.

Herzog, T. 1934. Studien über Drepanolejeunea II. Annales Bryologici 7: 54-94.

Infante, M., Heras, P. \& Buck, W.R. 1997. Bryophytes from the Republic of Equatorial Guinea (West-Central Africa). II. Bryophytes collected by Emilio Guinea (1907-1985) in the island of Bioco in 1947. Tropical Bryology 13: 131-135.

Longton, R.E. 1993. British Bryological Society Expedition to Mulanje Mountain, Malawi. 1. Background, itinerary and procedures.Journal of Bryology 17: 633-644.

Olarinmoye, S.O. 1974. Ecology of epiphyllous liverworts: growths in three natural habitats in Western Nigeria. Journal of Bryology 8: 275289.

Olarinmoye, S.O. 1975. Ecological studies on epiphyllous liverworts in Western Nigeria. I. Notes on distribution. Revue Bryologique et Lichénologique 41: 1-14.

O'Shea, B.J. 1993. British Bryological Society Expedition to Mulanje Mountain, Malawi. 2. Checklist of Malawi bryophytes. Journal of Bryology 17: 645-670.

Pócs, T. 1977. Epiphyllous communities and their distribution in East Africa.Bryophytorum Bibliotheca 13: 681-714.

Pócs, T. 1985. East African Bryophytes VII. The Hepaticae of the Usambara rain forest project expedition 1982. Acta Botanica Academiae Scientiarum Hungaricae 31: 113-133.

Pócs, T. 1993. New or little known epiphyllous liverworts, IV. Two new Cololejeuneoideae from the Comoro Archipelago. Journal of the Hattori Botanical Laboratory 74: 45-57.

Pócs, T. 1997. The distribution and origin of the foliicolous bryophyta in Indian Ocean Islands. Abstracta Botanica 21: 123-134.

Pócs, T. \& Tóthmérész, B. 1997.Foliicolous bryophyte diversity in tropical rainforests. Abstracta Botanica 21: 135-144.

Porley, R.D. 1997. British Bryological Society Expedition to Mulanje Mountain, Malawi. 8. Lejeuneaceae: Colura (Hepaticae). Journal of Bryology 19: 799-803.

Thorold, C.A. 1955. Observations on Theobroma cacao in Fernando Po. Journal of Ecology 43: 219-225.

Tixier, P. 1985. Contribution à la Connaissance des Cololejeuneoideae. Bryophytorum Bibliotheca 27: 1-439.

Tixier, P. 1995. Résultats taxonomiques de l'éxpedition BRYOTROP au Zaire et Rwanda. 30. Bryophytes épiphylles (récoltes de E. Fischer). Tropical Bryology 11: 11-76.

Vanden Berghen, C. 1951. Contribution a l'étude des espèces africaines du genre Ceratolejeunea (Spruce) Schiffn. Bulletin du Jardin Botanique de l'Etat à Bruxelles 21: 61-81.

Vanden-Berghen, C. 1978. Hépatiques Épiphylles récoltées en Rhodésie. Revue bryologique et lichénologique 44: 443-452.

Wigginton, M.J., Hodgetts, N.G. \& Porley, R.D. 200x. British Bryological Society Expedition to Mulanje Mountain, Malawi. 16. Cololejeunea lichenyae, sp. nov. (Hepaticae: Lejeuneaceae). Tropical Bryology. 
Table. 1. Occurrence of foliicolous taxa in two altitude ranges

\section{liverworts}

Aphanolejeunea capensis

Aphanolejeunea microscopica var. africana

Aphanolejeunea microscopica var. microscopica

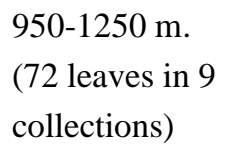

34

$1(1)$

$1.3981(19) \quad$ III

$11.30 \quad 10.29$

II

Aphanolejeunea truncatifolia

Caudalejeunea hanningtonii

Caudalejeunea lewallei

$1(1)$

(2) $\quad 5.55$

25 (11) II

$3.45 \quad 3.14$

II

Caudalejeunea sp. (sterile)

3 (1)

1.39

$6(4)$

0.82

0.75

Ceratolejeunea jungneri

$1(1)$

$4.162(1)$

0.50

Cololejeunea appressa

$2(2)$

$1.396(5)$

0.13

Cololejeunea cardiocarpa

5 (3) II

2.78

14 (2)

6.942 (1)

$0.27 \quad 0.63$

Cololejeunea distalopapillata

Cololejeunea duvignaudii

14 (4) III

19.4417 (12) II

$0.82 \quad 0.88$

Cololejeunea elegans

17 (3) II

19.4485 (18) III

8 (2)

23.6123 (4)

Cololejeunea lichenyae*

Cololejeunea malanjae

Cololejeunea minutissima

subsp. myriocarpa

$11.119(2)$

$36(6)$

0.25

$0.27 \quad 0.88$

$\begin{array}{lll}2.34 & 3.89 & \text { II }\end{array}$

$\begin{array}{lll}11.72 & 12.42 \quad \text { III }\end{array}$

$3.17 \quad 5.02$

$1.24 \quad 2.13$

$4.96 \quad 4.52$

11 (3) II $15.28312(35)$ IV

$43.03 \quad 40.53$

Cololejeunea obtusifolia

Cololejeunea occidentalis

Cololejeunea platyneura

Cololejeunea runssorensis

Cololejeunea tanneri

Cololejeunea tanzaniae

Cololejeunea tonkinensis

Cololejeunea zenkeri

Colura calyptrifolia

Colura digitalis

Colura tenuicornis

Colura usambarica

Diplasiolejeunea cornuta

Diplasiolejeunea kraussiana

Diplasiolejeunea symoensii

39 (3) II

$$
8(3)
$$

$1.10 \quad 1.00$

1 (1)

54.17

$1.3918(7)$

4.89

$2.48 \quad 2.38$

$$
1(
$$

$1(1)$ 155 (19) III

$21.38 \quad 19.44$

$0.69 \quad 0.63$

$$
1.39
$$$$
5 \text { (3) }
$$

0.13

$16(6) \mathrm{IV}$

$$
9(2)
$$

$1.24 \quad 1.13$

22.22

$$
2.01
$$

$5.66 \quad 5.14$

$41(8)$

$2.20 \quad 2.01$

15 (3) II

$16(2)$

$3.72 \quad 5.27$

$5.09 \quad 1.76$

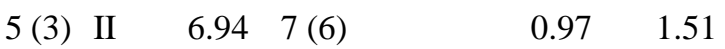

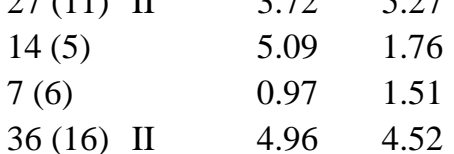

64 (10) II $\quad 8.82 \quad 8.03$

Drepanolejeunea cultrella

$1(1)$

Drepanolejeunea physaefolia

Drepanolejeunea pocsii

$1(1)$

1.3984 (23) III

$8.82-8.03$

101 (22) III

$11.58 \quad 10.66$

$13.93 \quad 12.67$

$1.395(4)$

$0.69 \quad 0.75$

12 (2)

$16.6716(5)$

$2.20 \quad 3.51$

1 (1)

$0.13 \quad 0.13$

\section{II}

II

Frullania apicalis 
Frullania arecae

Frullania capensis

Frullania gabonensis

Frullania lindenbergii

Lejeunea caespitosa

$21(8)$

$2.89 \quad 2.63$

Lejeunea aff. caespitosa

26 (10) II

$3.59 \quad 3.26$

Lejeunea confusa

Lejeunea eckloniana

5 (3)

$0.69 \quad 0.63$

Lejeunea flava agg.

Lejeunea hepaticola

Lejeunea isophylla

3 (1)

4.1628 (11) II

$3.86 \quad 3.89$

2 (2)

2.7829 (13) II

$4.00 \quad 3.89$

$$
2 \text { (2) }
$$

$0.27 \quad 0.25$

Lejeunea "longilobulata"

Lejeunea tabularis

3 (2)

$4.16 \quad 1(1)$

$0.13 \quad 0.13$

5 (3)

$0.69 \quad 0.63$

Lejeunea villaumei

Lejeunea sp. (sterile)

$35(8)$

$4.83 \quad 4.39$

2 (2)

$0.27 \quad 0.25$

Leucolejeunea xanthocarpa

Lophocolea muricata

9.7230 (16) II

3 (3)

$4.13 \quad 4.64$

7(3) II

1 (1)

$0.41 \quad 0.38$

Lopholejeunea sp. (sterile)

Metzgeria attenuata

Metzgeria consanguinea

Metzgeria decipiens

Metzgeria leptoneura

Metzgeria propagulifera

Metzgeria sp.

Microlejeunea africana

Microlejeunea kamerunensis

Plagiochila lastii

Plagiochila strictifolia

Plagiochila terebrans

Radula boryana

Radula comorensis

Radula holstiana

Radula lindenbergiana

Radula stenocalyx

Radula stipatiflora

Taxilejeunea conformis

\section{mosses}

Daltonia sp.

Fissidens sp.

Floribundaria sp.

aff. Lepidopilidium sp.

Pilotrichella sp.

Porotrichum sp.

Syrrhopodon asper

Thuidium ramusculosum

$0.13 \quad 0.13$

$0.13 \quad 0.13$

$1(1) \quad 0.13 \quad 0.13$

2 (1) $\quad 0.27 \quad 0.25$

$1(1) \quad 0.13 \quad 0.13$

$1(1) \quad 0.13 \quad 0.13$

$1(1) \quad 0.13 \quad 0.13$

22 (11) II $\quad 3.03 \quad 2.76$

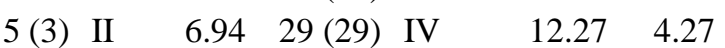

$1(1) \quad 1.39 \quad 9(6) \quad 1.24 \quad 1.25$

$1(1) \quad 0.13 \quad 0.13$

$2(2) \quad 0.27 \quad 0.25$

$3(2) \quad 0.41 \quad 0.38$

$3(2) \quad 4.16 \quad 1(1) \quad 0.13 \quad 0.13$

$1(1) \quad 0.13 \quad 0.13$

$4(1) \quad 0.55 \quad 0.50$

$2(2) \quad 0.27 \quad 0.25$

$3(2) \quad 0.41 \quad 0.41$

$2(1) \quad 2.78 \quad 5(3) \quad 0.69 \quad 0.88$

1 (1) $\quad 1.39 \quad 52(15)$ II $\quad 7.17 \quad 6.65$

II

$1(1)$

$1.3932(11)$ II

$4.41 \quad 4.14$

II

$1(1) \quad 0.13 \quad 0.13$

$3(2) \quad 0.41 \quad 0.38$

$12(3) \quad 1.66 \quad 1.51$

$2(2) \quad 0.27 \quad 0.25$

$3(3) \quad 0.41 \quad 0.38$

1 (1)

1.39

1 (1)

0.13

$0.13 \quad 0.13$

III

IV

II

V

TROPICAL BRYOLOGY 20 (2001) 
Number of taxa per collection (relevé) 1-11 (mean: 6.7) 2-23 (mean 9.9)

* sp. nov. to be published in a forthcoming paper

Columns 1, 4. The number of leaves on which the taxon was detected (no. of collections in which the taxon was detected ).

Columns 2, 5, 8. The constancy of occurrence of taxa in collections [only II-V shown].

Column 3, 6, 7. The percentage frequency of occurrence on leaves (950-1250 m alt.).

Constancy: $[\mathrm{I}=1-20 \%] ; \mathrm{II}=21-40 \% ; \mathrm{III}=41-60 \% ; \mathrm{IV}=61-80 \% ; \mathrm{V}=81-100 \%$.

Table 2. Conversion of UTM Grid to Latitude and Longitude

\begin{tabular}{|c|c|c|}
\hline UTM Grid & \multicolumn{2}{|c|}{ Latitude and Longitude } \\
\hline 6736 & $15^{\circ} 56^{\prime} \mathrm{S}$ & $35^{\circ} 29^{\prime} \mathrm{E}$ \\
\hline 6936 & $15^{\circ} 56^{\prime} \mathrm{S}$ & $35^{\circ} 31^{\prime} \mathrm{E}$ \\
\hline 7227 & $16^{\circ} 01^{\prime} \mathrm{S}$ & $35^{\circ} 32^{\prime} \mathrm{E}$ \\
\hline 7232 & $15^{\circ} 58^{\prime} \mathrm{S}$ & $35^{\circ} 32^{\prime} \mathrm{E}$ \\
\hline 7233 & $15^{\circ} 57^{\prime} \mathrm{S}$ & $35^{\circ} 32^{\prime} \mathrm{E}$ \\
\hline 7238 & $15^{\circ} 55^{\prime} \mathrm{S}$ & $35^{\circ} 32^{\prime} \mathrm{E}$ \\
\hline 7239 & $15^{\circ} 54^{\prime} \mathrm{S}$ & $35^{\circ} 32^{\prime} \mathrm{E}$ \\
\hline 7240 & $15^{\circ} 53^{\prime} \mathrm{S}$ & $35^{\circ} 32^{\prime} \mathrm{E}$ \\
\hline 7330,7429 & $15^{\circ} 59^{\prime} \mathrm{S}$ & $35^{\circ} 33^{\prime} \mathrm{E}$ \\
\hline 7331,7332 & $15^{\circ} 58^{\prime} \mathrm{S}$ & $35^{\circ} 33^{\prime} \mathrm{E}$ \\
\hline 7333 & $15^{\circ} 57^{\prime} \mathrm{S}$ & $35^{\circ} 33^{\prime} \mathrm{E}$ \\
\hline 7431 & $15^{\circ} 56^{\prime} \mathrm{S}$ & $35^{\circ} 33^{\prime} \mathrm{E}$ \\
\hline 7438 & $15^{\circ} 55^{\prime} \mathrm{S}$ & $35^{\circ} 33^{\prime} \mathrm{E}$ \\
\hline 7529 & $15^{\circ} 59^{\prime} \mathrm{S}$ & $35^{\circ} 34^{\prime} \mathrm{E}$ \\
\hline 7532 & $15^{\circ} 58^{\prime} \mathrm{S}$ & $35^{\circ} 34^{\prime} \mathrm{E}$ \\
\hline 7635 & $15^{\circ} 56^{\prime} \mathrm{S}$ & $35^{\circ} 34^{\prime} \mathrm{E}$ \\
\hline 7735 & $15^{\circ} 56^{\prime} \mathrm{S}$ & $35^{\circ} 35^{\prime} \mathrm{E}$ \\
\hline $7840,7841,7941$ & $15^{\circ} 53^{\prime} \mathrm{S}$ & $35^{\circ} 36^{\prime} \mathrm{E}$ \\
\hline 7939 & $15^{\circ} 54^{\prime} \mathrm{S}$ & $35^{\circ} 36^{\prime} \mathrm{E}$ \\
\hline 8031,8032 & $15^{\circ} 58^{\prime} \mathrm{S}$ & $35^{\circ} 37^{\prime} \mathrm{E}$ \\
\hline 8237,8337 & $15^{\circ} 55^{\prime} \mathrm{S}$ & $35^{\circ} 38^{\prime} \mathrm{E}$ \\
\hline 8239 & $15^{\circ} 54^{\prime} \mathrm{S}$ & $35^{\circ} 38^{\prime} \mathrm{E}$ \\
\hline 8241 & $15^{\circ} 53^{\prime} \mathrm{S}$ & $35^{\circ} 38^{\prime} \mathrm{E}$ \\
\hline 8335 & $15^{\circ} 56^{\prime} \mathrm{S}$ & $35^{\circ} 38^{\prime} \mathrm{E}$ \\
\hline 8433,8434 & $15^{\circ} 57^{\prime} \mathrm{S}$ & $35^{\circ} 39^{\prime} \mathrm{E}$ \\
\hline 8435 & $15^{\circ} 56^{\prime} \mathrm{S}$ & $35^{\circ} 39^{\prime} \mathrm{E}$ \\
\hline 8441 & $15^{\circ} 53^{\prime} \mathrm{S}$ & $35^{\circ} 39^{\prime} \mathrm{E}$ \\
\hline 8532 & $15^{\circ} 58^{\prime} \mathrm{S}$ & $35^{\circ} 40^{\prime} \mathrm{E}$ \\
\hline 8740 & $15^{\circ} 53^{\prime} \mathrm{S}$ & $35^{\circ} 41^{\prime} \mathrm{E}$ \\
\hline 9041 & $15^{\circ} 53^{\prime} \mathrm{S}$ & $35^{\circ} 42^{\prime} \mathrm{E}$ \\
\hline 9126 & $16^{\circ} 01^{\prime} \mathrm{S}$ & $35^{\circ} 43^{\prime} \mathrm{E}$ \\
\hline 9127,9227 & $16^{\circ} 00^{\prime} \mathrm{S}$ & $35^{\circ} 43^{\prime} \mathrm{E}$ \\
\hline
\end{tabular}

TROPICAL BRYOLOGY 20 (2001) 
